\title{
LA INVESTIGACIÓN CIENTÍFICA: ACTITUD DE CAMBIO PARA LA UNIVERSIDAD MODERNA
}

\section{María Cristina SAN MIGUEL ${ }^{1}$.}

${ }^{1}$ Directora de la Filial Santa Rosa del Aguaray, Facultad de Ciencias Médicas, Universidad Nacional de Asunción, Santa Rosa del Aguaray - Paraguay. Editora Asociada, Revista Medicina Clínica y Social.

Cómo citar este artículo: San Miguel MC. La investigación científica: actitud de cambio para la Universidad moderna. Medicina Clínica y Social. 2017;1(1):2-3.

¿Qué se entiende por Investigación en la Universidad en nuestro país y en nuestra comunidad? ¿Cómo se desarrolla? ¿Cómo llevarla a cabo? Sin duda, investigar es un proceso que implica conductas de cambio, alimentando, una y otra y otra vez, en el terreno fértil de mentes individuales, el germen de la curiosidad por el mundo y sus partes, por sus cualidades y relaciones, sus procesos y su funcionamiento.

La diseminación de ese germen puede darse en casa, en el terreno, en un libro, en el aula, o en un laboratorio. Sin embargo, para que el desarrollo profesional de la investigación científica pueda establecerse, se necesitan muchos más elementos: se requiere enseñanza estructurada y sistemática del conocimiento, organización académica e institucional, insumos, equipos y recursos, creatividad, voluntad política, sentido humano, y vinculación social y académica. Se precisa todo esto en forma continua y sostenida. Pero, fundamentalmente, se necesita instalar la duda como combustible inalienable de los conocimientos, y no solo la ósmosis de contenidos alejados de nuestra realidad, contenidos muchas veces no acordes con nuestro medio ambiente tan particular.

La Universidad es hoy un lugar propicio para la investigación científica pues, a lo largo de su existencia, gracias al esfuerzo de innumerables voluntades (investigadores, profesores, trabajadores y funcionarios) y con base en la libertad de cátedra y de investigación, ha reunido todos estos elementos (desde la curiosidad básica hasta la infraestructura, aunque mínima) para permitir e impulsar su desarrollo.

En la actualidad uno de los mayores retos de la sociedad está representado en qué tanto avanza la ciencia y la investigación, en todas las áreas del conocimiento, con la ayuda de la informática y la tecnología. En Paraguay, aún es bajo el índice de inversión económica del Estado en materia de apoyo a los procesos investigativos y científicos, lo cual evidencia nuestro retraso con respecto al concierto latinoamericano y mundial. En esta perspectiva, resulta de singular importancia consolidar un espacio de reflexión institucional sobre las condiciones, características y políticas de ciencia y tecnología en el país, así como del estado actual de la investigación científica en algunos campos estratégicos del conocimiento.

Según los últimos datos recopilados por el Banco Mundial, durante el periodo 2005-2014, los países que encabezan la lista con el mayor porcentaje de inversión del Producto Interno Bruto (PIB) son: en primer lugar, Israel con 4,21\%; en segundo, la República de Corea, con $4,15 \% ; y$, en tercer lugar, Japón con 3,47\%. Por el contrario, El Salvador (0,03\%), Mónaco y 
Guatemala (ambos con el 0,04\% del PIB) son los países que menos aportan a la investigación y desarrollo de ciencia y tecnología. La mayoría de las naciones latinoamericanas no contribuye ni con el $0,5 \%$ de inversión en este rubro, tal es el caso de Chile $(0,36 \%)$, Ecuador $(0,34 \%)$, Colombia $(0,23 \%)$, Panamá $(0,18 \%)$, Bolivia $(0,16 \%)$ y Paraguay $(0,09 \%)$ (1). Algo debe hacerse para lograr que el germen de la investigación prenda a pesar de las dificultades estructurales presentes en el terreno.

Es este sentido que, desde la Filial de Santa Rosa del Aguaray de la Facultad de Ciencias Médicas de la Universidad Nacional de Asunción, se quiere aportar -tal vez de manera utópicaal proceso de generación del conocimiento y la divulgación científica a través de la publicación de la primera Revista revisada por pares del norte del país. Esperamos que esta apuesta crezca con sentido crítico, llena de dudas, que forme una raíz rebelde y enriquecedora de una nueva sociedad, con el esfuerzo de los profesores, estudiantes y de los actores sociales que conforman las ciencias de salud regional.

\section{CONFLICTOS DE INTERÉS Y FUENTE DE FINANCIACIÓN}

La autora declara no poseer conflictos de interés. Fuente de financiación: ninguna.

\section{REFERENCIAS BIBLIOGRÁFICAS}

1. Banco Mundial [Internet]. Washington: Gasto en Investigación y Desarrollo. [Citado el 30 de abril de 2017]. Disponible en: http://datos.bancomundial.org/indicador/GB.XPD.RSDV.GD.ZS 


\section{SCIENTIFIC RESEARCH: AN ATTITUDE OF CHANGE FOR THE MODERN UNIVERSITY}

\section{María Cristina SAN MIGUELํ․}

${ }^{1}$ Director, Santa Rosa Campus, School of Medical Sciences, National University of Asunción, Santa Rosa del Aguaray - Paraguay. Associate Editor, Journal Medicina Clínica y Social.

How to cite this article: San Miguel MC. La investigación científica: actitud de cambio para la Universidad moderna. Medicina Clínica y Social. 2017;1(1):2-3.

What do we understand by research at the University setting in our country and in our community? How does it develop? How can we carry it on? Without doubt, doing research is a process that implies changes in our conduct, nourishing once and again in the fertile terrain of individual minds, the seed of curiosity about the world and its parts, about its qualities and its relationships, its processes and its inner workings.

The spread of this seed can be done at home, in the field, in a book, at the classroom, or at a lab. However, in order to achieve the professional development of scientific research, more elements are needed: we require structured and systematic teaching of the knowledge, academic and institutional organization, supplies, equipment and resources, creativity, political will, a sense of humanity, and social and academic relations. All of these things are required in a sustained and continuous way, but, mainly, we need to make doubt the unassailable fuel of knowledge, instead of the osmosis of contents far from our reality, contents not always aligned with our very particular environment.

The University is today a very favorable place for scientific research because, throughout its existence, and through the effort of innumerable actors (researchers, professors, and employees) and based on the freedom to teach and to investigate, it has aggregated all these elements (from basic curiosity to infrastructure, although very minimal) to allow and propel its development.

Nowadays, one of the biggest challenges of our society is that at a time when science and research in all areas of knowledge are advancing like never before, especially through technology and the gathering and processing of data, in Paraguay, spending in research and science in general is still scarce. This situation reveals that we still have a long distance to go in order to be in tune with the world and our continent in this subject. From this optic, consolidating a space for institutional reflection about the conditions, characteristics and politics that surround science and technology in our country, as well as the status of scientific research in strategic fields of knowledge becomes paramount.

According to the latest figures published by the World Bank, in the period 2005-2014, the countries with the largest percentage of their GDP invested in research are Israel, with 4.21\%; Korea, with 4.15\%; and Japan, with $3.47 \%$. On the contrary, El Salvador $(0.03 \%)$, Monaco and Guatemala (both with $0.04 \%$ of their GDP) are the countries that invest less in research, science and technology. Most of Latin-American countries invest less than $0.5 \%$ in 
these areas, such as Chile (0.36\%), Ecuador (0.34\%), Colombia $(0.23 \%)$, Panamá $(0.18 \%)$, Bolivia $(0.16 \%)$, and Paraguay (0.09\%) (1). Something must be done to spark an interest in research, despite the structural deficiencies in these countries.

It is in this spirit that, from the Santa Rosa campus of the School of Medical Sciences of the National University of Asunción, we want to contribute -perhaps in a utopic way- to the process of generating knowledge and spreading scientific information through the publication of our first peer-reviewed Journal. We hope that this project will grow with a critical mind, full of doubts and will form a rebel root that will enrich our society with the effort of professors, students and social actors who constitute the pillars of the regional health science studies.

\section{CONFLICTS OF INTEREST AND FUNDING}

Conflicts of interest: none. Funding source: none.

\section{REFERENCES}

1. Banco Mundial [Internet]. Washington: Gasto en Investigación y Desarrollo. [Cited 30 April 2017]. Available at: http://datos.bancomundial.org/indicador/GB.XPD.RSDV.GD.ZS 